\title{
A Traditional Communication of Bugis (Note 1) in the South Sulawesi of Indonesia through the Art Performance of Kecapi
}

\author{
Muslimin M. \\ ${ }^{1}$ Faculty of Social and Political Science, University of Muhammadiyah Malang, Indonesia \\ Correspondence: Muslimin M., Lecturer Communication Sciences, Faculty of Social and Political Science, \\ University of Muhammadiyah Malang, Indonesia. E-mail: machmudmus@gmail.com
}

Received: August 8, 2016

doi:10.5539/ass.v13n3p21

\author{
Accepted: December 10, 2016 \\ Online Published: February 15, 2017 \\ URL: http://dx.doi.org/10.5539/ass.v13n3p21
}

\section{Introduction}

Discussing about traditional communication, it is commonly connected to the tradition concept, which contains a meaning that the concept is a kind of the past finding, but it is commonly reputed as a normative thing by each part of the society. Based on the explanation, it can be concluded that the definition of traditional communication is commonly connected to the folk art performance as a traditional media that is owned by a certain society, as the result it can be identified and understood that a folk art performance is owned by that society and exist as a local wisdom for the society.

Therefore, it can be cleared that discussing about traditional communication is cannot be separated with the traditional folk art performance as a media, a kind of art that is based on the folk story by using media that appears and develops in a certain society. The effort of source finding of this folk story is not only purposed to be performed in the form of art performance, but also it is further expected to carry out messages from the story. Therefore, in the review of traditional communication it is emphasized to the way of carrying the messages that are contained in an art performance as a media. Therefore, this review is not discussed about the art performance furtherly. It means that the performance can use a great and luxurious background, but also can be in a simple form.

South Sulawesi as a former government of the Indonesian Archipelago (the government of Gowa-Tallo and other governments that had been exist in Indonesia) has various kinds of art performance of the traditional media which are still heired for generations, where the function of traditional media is not only as an entertaining public show, but also may be a guidance because of the role of art performance which is full of messages and senses.

Therefore, people who will have an art performance are commonly have to prepare their physic, mental, and psychology, moreover in fact that they will face most of audiences and have an all night (Note 2) performance. So that, in the South Sulawasi, may be in other places, before playing the role as a persistent player in an art performance, the players are commonly practice hard their skill and ability. This ability is usually completed by a mysthical thinking through the magic words or Parimbolo (Bugis' language). In order to learn the magic words, the players commonly meet the elders, but the magic words are not directly given, but rather have to pass some rituals within certain rules such as white cloth, a cock, or by preparing black sticky rice and black cock (Ajeip Padindang in Monoharto, 2003: ix-x).

\section{The Meaning and Function of Kecapi in the Comunication Process of Bugis Community}

One of buginese figure who cares about the art performance of Kecapi is Mr. H. Ma'ruf Saleh, 66 years old, he works as a society elder and the owner of the traditional media community of art performance of Kecapi who lives in Rappang, Sidrap regency. Eventhough he leads and owns the Kecapi performance community, but he is occasionally play it, particularly if there are invitations of the famous people in the South Sulawesi or if there are children and youngsters as individual or group who have high desire to play Kecapi so he will teach them with his pleasure.

Mr. H. Ma'ruf Saleh said that it is difficult enough to explain the history of when Kecapi is firstly performed, definitely it had been existed since the period of Tomanaurung and the former kings. The Kecapi players are usually invited to the palace in order to entertain the king and his family. Likewise, it is performed to support the government armies before leave to war and after come from there. While, in the ordinary society, Kecapi is also 
very populer. It is played by the farmers while looking after their plants on the farm, and also played by the herdsmen while looking after their browsing livestocks such as cow or bufallo. In the past, Kecapi is heard almost in the entire village, in the people houses, farms, fields, even under the dense trees where the herdsmen take a rest while playing the Kecapi. It means that at that time Kecapi is played by the people to enjoy themselves.

In the beginning, Kecapi is only played as an instrument in order to entertain people by the players' amusing motion and action, then it develops become a performance that integrates the sound of Kecapi along with the rhyme in the form of long story about heroism, values educating, moral educating, magnigicience and religion, criticism and social control even life philosophy. Eventhough the performance of Kecapi is occasionally start from 9 p.m. until dawn, but the listeners are not bored. It is caused by an unsatisfied feeling when the people watch an unfinished Kecapi performance.

In the period of colonization of Dutch or Japan, Kecapi is used as a joint entertaining media between the colonial with the indigene, but it is played in group and performs together with other instruments such as Kendang, flute, along with singer and dancer which are called as Biduan. Most of the Biduan are transsexual people or called as Waria (read: man which has personality as woman). Because the main purpose is to entertain the colonial armies. Why Waria which is performed, because at that period if woman who is performed, those colonial armies, both Dutch or Japan, will force her to get in touch intimately.

The next development, Kecapi is started to be contested both individual or group, even nowadays the Kecapi performance is started to be commercialized. The Pakkacapi (Note 3) CD and DVD are mostly sold in the cassette shops, however the weakness is that it does not has a clear rule about who is the producer, how the income sharing system between the producer and player, and who will control the selling system. It means that the contract is not clear. Nowadays, people who have a party are usually rent pakkacapi for entertaining and enlivening that party within the agreed payment. By this condition, it can be concluded that Kecapi have been a folk entertaining media as professionally, so it can become a livelihood.

Mr. H. Ma'ruf Saleh also explains that in the formal programs, when pakkacapi is performed, the people have to wear the Buginese costume such as traditional costume, head fastener (read: Pasapu), and the Buginese silk sarong. Besides if there is invitation from the political party, the Kecapi players will adjust with that party uniform color, as an example if the Kecapi players are invited by the Party of Golkar, they will wear the yellow costume and sarong, while if they are invited by PDIP, so the costume and sarong must be red, thus the Kecapi players will adjust as the request of the invitor even it is not from a political party.

Thus, the traditional attributes in every place are commonly different, for example is the head fastener. In a discussion that is held in Sidrap, it is decided that the head fastener is become a Buginese symbol, it is Songkok To Bone ${ }^{2}$, but when they perform in another place, they get a warning from the elders of that place, because they assume that Songkok To Bone (Note 4) is only wore by the Buginese noble. Based on that case, it seems that there is a perception differentiate about the attributes or symbols that are used between the players with the audiences that is represented by the elders. It can be seen as a further development of the traditional media existence in the form of art performance of Kecapi in Bugis.

Occassionally, Mr. Ma'ruf Saleh is apprehensive about the way of thinking of the young generation nowadays, he explains that since the modern media such as movie, television, CD and DVD are easily spread to the entire of the village, most of the young generations are shame and awkward to play Kecapi, it is reputed as an old-fashioned thing. When in the past two person or more will play Kecapi, now they are prefer to play guitar, because it is seen as a modern one. The impact of this condition will be seen explicitly toward the way of thinking of the young citizens. This kind of tendency will be a certain defiance for Mr. Ma'ruf and his community, although it will be difficult however the early condition must be returned even it is cannot perfectly returned. However, there must be an effort to realize that aim.

Based on the research that has done by the writer, it seems that there is a concrete effort by Mr. Ma'ruf and his community to develop the studio, where young generatios are involved, moreover when there is a champion or competition so the participants are mostly the teenagers, it seems that they start to have desire in playing Kecapi. Moreover, they will get a payment if they are able to perform in the public ceremony or party

Meanwhile, about the governement action, Mr. Ma'ruf Saleh explains that it is depend on the regent. Occassionally, there is a regent who gives a serious attention toward the art performance of Kecapi, in the other side there is a regent who does not give any attention. When the regent gives an attention, the art performance of Kecapi will be popular, besides there are many of competitions, it will be involved in the local curriculum, moreover the government will set an estimation cost for providing, preservating, and founding. In the other way, 
if the regent is not interest to it, as the result is the art performance of Kecapi is become 'slack'. Kecapi will be only played by a certain art community or its own society.

Furthermore, Mr. Ma'ruf explains that nowadays the government still has an attention, even it is limited to the cost estimation for giving a trainee for the teachers and they are expected to be able to teach the students. Meanwhile, the Kecapi players group always do a hard effort in order to balance the modern media by keep their consistence toward the art performance of Kecapi. Eventhough there is low estimation cost, but they always make a serious effort in order to make the traditional media of Kecapi is always exist.

An explanation that is related to the art performance of traditional media of Kecapi is also defined by Mr. Sabri Nangka, 37 years old, he works as a farmer and a famous Kecapi player in the South Sulawesi, moreover his recording in the form of CD and DVD are spread around the Center Sulawesi, Borneo and Java. After winning a championship ( 1st rank) or Kecapi competition which is held in Pinrang regency, there are producers who offer for recording because of his skills in playing Kecapi. He is able to cover and play some songs from the famous singers such as H. Rhoma Irama (Indonesian King of Dangdut). Therefore, in the South Sulawesi especially in the some place of Buginese, most of cassete shop and people houses have his CD or DVD .

Mr. Sabri, his nickname, explains that he cannot remember the exactly time he plays Kecapi, definitely he was a child. He also cannot explain that children who plays Kecapi, when he was a child, are purpose to preserve it or not, because his village is located on the edge of mountain so there is no entertainment, no one have television and only a few who have radio, therefore the people usually play Kecapi or bamboo flute while looking after the farm or livestock. The people usually create the instrument by themselves.

The stories that are sung are verbal stories that are heard from the elders who also play Kecapi, so its characteristic is a verbal story which is heard verbally then imitated by the generations. Therefore, most of the Kecapi players are able to memorize the rhyme of the former Kecapi players, based on the history, the heroism of Kahar Muzakkar, love story of the kings, also an advice for the children, teenagers, women, parents, even a story that is aimed to motivate children to study hard, it means that in playing Kecapi the educational substance is also noticed.

Mr. Sabri expects to preserves the art performance of Kecapi in Bugis, therefore he says that he will always play Kecapi, moreover it has been the part of his life, even he is still farming but Kecapi is his priority. In order to preserve the performance of Kecapi, he exercises the teenagers in his village. Commonly the exercise is done in the patrol post in the night, he invites the teenagers then practice to play Kecapi together, and it will be seen teenagers who have a natural talent. It is a needed basic to be famous player, so they are able to play professionally in the art performance of Kecapi. It is expected that one day the art performance of Kecapi can be everlasting and heired for the next generations. In order to preserve the Kecapi playing, it cannot be done only by Mr. Sabri as a player, but it will be better if the government, private company, or other cultural observers give a serious attention. Because they are duly participate in preserving the art perfromance of Kecapi.

Related to the reaction of the young generation, Mr. Sabri explains that event many young generations who do not interest in playing Kecapi, he believes that the performance of Kecapi in Bugis will always develop, it is based on the fact that everywhere he performs Kecapi, the audiences are seemed to be enthusiastic on it, and basicly many villagers' children who still play Kecapi as their entertaining media, therefore according to him, the most important thing is how every part of the society has an awareness to train the children who have a desire in playing it. Furthermore, Mr. Sabri states that playing Kecapi is owned by the society, it means that originally it is sourced from the society, so that it plays in every people party or ceremony.

Since participating in the Kecapi championship or competition, Mr. Sabri begins to be popular in public as the result he accepts many invitations, even occassionally he cannot fulfill all of them. Thus, some of cassette producers interest to record his performances then commercialize it. Some recording have been taken, but Mr. Sabri realizes that some of them have unclear contracts, as the result he receives a payment only when take the record, then he does not receive any payment from the CD or DVD selling (Note 5).

Mr. Sabri is not only invited by the people in the South Sulawesi, but also Palu and Borneo. The invitors are the Bugineses who live there. They state that Mr. Sabri expects to introduce the Buginese culture, because it is a special pride for a villager who only can play Kecapi. Moreover, in the moment of general election, there are political parties who invites the Kecapi players for giving entertainment to public. They are sure that campaign by using traditional media of Kecapi, especially in the villages, it will be able to influence the constituents.

The main constraint that is felt by Mr. Sabri as a Kecapi player is the less attention from the various sides, there is unserious effort to develop the contain that will be performed, it means that the matter is still the same as the 
past. For example if he performs a historical story, it is begun from the same character, place, even plot, eventhough the sense of humor that is performed by the players is able to keep the audience enjoy the performance, but it is still have the same elements. Mr. Sabri expects that there will be some helps in creating a readable script to be performed in the form of story rhyme, so the audiences are able to get new information or message. If it can be realized, he expects that the script is appropriate with the nowadays condition.

The writer also finds another informant about traditional media performance of Kecapi in Bugis. He is Mr. H. M. Yunus Nur, 53 years old, who lives in Pinrang, South Sulawesi. Besides as an inhabitant, he also works as the owner and manager of Simpang Pinrang Radio, a private radio which is built by himself. He confesses that he loves the art performance which can be categorized as a traditional media, especially Kecapi. Because of his amorousness toward the art performance of Kecapi, he establishes a special night program about Buginese Kecapi on his radio. Discussing about the beginning of his anxiety to play it, He explains that he has been interested on it since he was a child, he saw almost every Kecapi performances. His anxiety becomes stronger during his teenager, therefore he always see the Kecapi performance which is held in the field, building, even listen radio. Because of his job is about media, so he creates a night program that is named pakkacaping by inviting the Kecapi player directly or playing cassette.

The main reason of his anxiety in playing Kecapi is its legend that is rhyme verbally by the players and variated by fresh humor so it can entertain the listener give knowledges about historical values, honesty, justness, bravery, and reverence toward human, nature even God. Moreover, there are Kecapi players who are able to deliver the messages through the story that are related to Islam.

Mr. Yunus explaines that beside playing it, there are art performances that are can be categorized as traditional media in Bugis such as Elong Pelong (Buginese songs), one of effective traditional media in order to share thought and feeling of the player or listener. Therefore, Buginese people use Elong Pelong as a media to teach children about values. In the other side, there is also a traditional media that is used as a media for solving the society's problems, it is called Tudang Sipulung. Meanwhile, the people is still use Kentungan for announcing certain informations such as fire, flood, death, or the sign to gather the people on the fild.

Another Buginese traditional media is Mappadendang, it is played for expressing the people happiness after harvesting, especially for the youngster. The other is Pappaseng which is used as a guidance in implementing and arranging the government, it is also used as the source in educating good attitude and moral value. However, Mr. Yunus states that almost all of those traditional medias is rarely found nowadays. Therefore, he tries hard to preserve the traditional media especially owned by the Buginese. It is the reason of why Mr. Yunus very adore Kecapi performance, because he thinks that there is rare of people who mastering it, thus he tries to make it popular by broadcast it on his radio. Apparantly, it has many listeners that come from villagers or citizens.

At a moment, when Mr. Yunus is trusted to hold Kecapi championship by a private company which is also used to promote that company's product. The result is unbelievable, the people have a high interest on it, there is also a high desire of the audiences in watching it. The company owner, as the main funder, reveals that the program is held successly, as the result the company's purpose to introduce its products is also success. Moreover, after the competition, there are many CD and DVD of Kecapi performance which is sold. Eventhough the buyers are mostly old people above 40 years old. Therefore, according to Mr. Yunus, the marketing media is not only a modern media, but also the traditional such as Kecapi and other traditional media which is very effective and efficien for introducing a product to public, especially the inhabitants.

He also states another explanation that his adority toward Kecapi performance is caused by its positive message for educating and introducing values, also because of the audiences' participation in every show, so the audiences are entertained by the message delivering which is expressed by singing the rhyme spontainiously. The message is delivered effectively because it has a direct corelation of the people live. Besides, there is an interactive dialogue between the players and audiences.

Eventhough, most of Kecapi players have low education level, but they have a natural high talent and desire, and also they do not have a commercial desire in playing it, therefore they are able to perform a high quality performance. Almost all of the story in the Kecapi performances have been performed in the other places, but it is still interesting because the Kecapi players have skill to do a good movement or express an enjoyable humor. Moreover, the movements do not change the main messages of the performance. Even the players are different, but when they perform a same story, the messages which are delivered are same, eventhough there is no written source. Because all of the sources are brought from the former Kecapi players verbally.

Related to the action of the young generations, Mr. Yunus explains that when the competition is held, the audiences are spread evenly from the children to the old. However, based on the players, it seems that the young 
generations do not too interest in it. It is possibly caused by a thought that Kecapi is old fashioned. Particularly the young generations who live in the city, they do not have desire to play it. They only want to listen or watch the performance, but not for practicing.

Related to the preserving way of the art performance of Kecapi, Mr. Yunus gives his opinion that some Buginese Kecapi communities take their own way.it is difficult to gather them in order to preserve the art of Kecapi. The preserving way is also done apartly, for example is teaching the youngster in their surrounding, or even just teach their children. It seems that the government does not implement a serious preserving. The government is occassionally set an estimation cost for the players, moreover if they are invited to perform or participate a competition in the other regions, but it have to submitted early, if it does not submitted early, the estimation cost will not be estimated. Absolutely, it becomes a serious problem for the Kecapi players.

Based on the government side, the preserving effort is decided by the regent. If he adores in art, the art performance will be develop well, but on the contrary the government will not give a serious attention. The more effective preserving way is commonly done by the companies who are apprehensive about the Buginese culture. Therefore, Mr. Yunus who adores Kecapi performance tries to develop and preserve it individually. For example is by introducing and offering its performance toward the businessmen, so they will always invite pakkacapi in their party or ceremony.

This way is more effective, because it is proved that after holding a Kecapi championship or competition, the Kecapi players accept more invitations. Moreover, they are occassionally cannot accept the invitations because it is too much. This condition causes some privat companies or bank interested to exploit the traditional media of art performance of Kecapi to promote their products. It means that the traditional media of art performance of Kecapi has a new function as a promotion media that is seemed more effective.

In order to get a detail information about the Buginese traditional media, the writer comes to an informant who is the Buginese elder and also the Lontara translator (Old Buginese scripts). He is ever invited to Dutch in order to translate the script of La Galigo in the Leiden library, Dutch. He is Mr. H. M. Salim, 71 years old, who lives in Makassar and a pensioner from the Department of Education and Culture of South Sulawesi. Mr. Salim, his nickname, explains that the traditional media in the South Sulawesi has been existed since Batara Guru is delegated as the first person in the Bugis, it is also told in the script of Lontarak or I Lagaligo, for example is the using of tool and art performance in the variety of ceremonies that is called as traditional media. Other examples are the using of Kecapi, Folk Dances, Tudang Sipulung, Pappaseng, Mappadendam, Elong Pelong, and Kentongan as the society communication media. Those are the main equipment for the ceremonial process that is done by the Bissu as the group of Tomanurung in the past.

In the kingdom period, the traditional media is also known even the function has been changed. The traditional media in that period is not only as the ceremony equpment, but also as an entertainment and giving information for the society, or in the other side it can be performed as a message delivery or the people action to the government. Thus, in that period the traditional media is functioned as an effort to build the people in teaching values, magnigiciencing a religion, delivering information about the kingdom rules or the society education.

Nowadays, actually there are traditional media which have the same meaning as the past, but they do not have an opportunity to perform it because the youngsters are more interested in the modern media. This fact should be noticed by every individual so the traditional media is able to be preserved. For examples are Pappaseng, mappadendang, and elong pelong which are rarely performed, eventhough they contain of positive messages about good attitude, teaching values, moral, religion, the correlation between human and nature, social control and criticism and other positive messages for children, even the youngsters.

Papaseng, Mappadendang, and Elong Pelong are the kinds of art performance which are aimed to deliver messages as explained above, the source is read from the Lontarak Attorioloang (the former's holy book), they are performed in a certain moment, especially when the people hold a ceremony or party individually or together, for example is a harvesting ceremony. The art performance is performed to express a gratitude to God. Therefore, since long time ago, the art performance is able to give a positive benefit for the people. Moreover, that media is not only become an entertainment, but also a guidance.

Mr. Salim also explains that the first time of the existence of traditional media, it contains much of myths, for example is the story of Miong Palo Karellae (spotted cat) which is accompanying the goddess of rice rounding the South of Sulawesi, the leadership of Sawerigading, or I La Galigo, and other myth stories. Those stories are mostly give a good guidance for the social life, they teach the human to live normally (in the good line). It can be defined that not all of myths give a negative impact, some of them which are performed as traditional media can be a good life guidance. 
In order to keep the existance of Buginese traditional media, Mr. Salim assumed that it needs a cooperation and high desire of many sides, from the government, cultural observer, traditional media community, and privat company. If they are able to create an effective cooperation, so the traditional media is able to be preserved. The meaning of cooporation above is the government and private companies set an estimation cost, then the cultural observer and traditional media community give a speciall training or electing the talented young generations. Thus, the traditional media is able to be preserved.

A review that is related to the performance of traditional media in Bugis is also stated by Mr. Abduh, 53 years old, besides as an admirer of the traditional media, he also works as a journalist. He ever becomes an art performance of traditional media trainer of Mappadendang. He expalains that he loves an art performance which is formed as a heritage from the formers such as Kecapi or the art performance of Mappadendang. Meanwhile, he confesses that almost every night he watch or listen to it. Moreover, he has his own collection to be heard while driving. Actually, Mappadendang only can be performed while harvesting time, Mr. Abduh as a Mappadendang trainer states that it is performed as the people's gratitude to the God. Mr. Abduh as a Mappadendang player is also a Silat trainer (traditional self-defence arts). Because the performance of Mappadendang usually integrates of the movement art and the sound of the rice pounder which are called as alu sibawa palungeng (Read: the rice pounder with a mortar). (Note 6)

Mr. Abduh reasons of loving the traditional media are beside entertaining, Kecapi performance and Mappadendang are also full of good meanings that teaching about values and wises. So that it is not only an entertainment, but also as a guidance. As an entertainment because it entertains the audiences, and as a guidance because it is full of messages about moral value, religion, attitude, and positive advice. The messages about human life, education, attitude, children attitude toward their parents, heroism, history, value, kingdom story, romance, moral, religion, social, health, and the others are delivered clearly. The topic is taken from some sources then improved by the players in order to create a good rhyme which is enjoyable to be watched or listened.

He is occassionally laugh by himself while listening the rhymes that is performed in the Kecapi performance, thus he can be relaxed after working all day. Therefore, Mr. Abduh states that the messages which are delivered by the art performance of Kecapi and Mappadendang are very valuable particularly in teaching values to the children also for the social people.

Especially, he states that his interesting in Mappadendang because the messages which are delivered ara understandable by the soicety, it is about persuade people about gratitude to the God because of the harvesting result. Thus, the messages which are delivered can be an information to the people that in that place will be held a wedding ceremony. Furtherly, Mr. Abduh states that in the past, Buginese wedding ceremony is a kind of extravagant ceremony which is held after the harvesting time, therefore before it is held they have to prepare various nessecities including pounding the rice for that ceremony. Pounding rice is not only done by the familiy member, but also by the close neighboor even the far neighboor, they come to help by bringing the rice pounder (in the Bugis language called by $a l u$ ). It is aimed to make the hostess happy, they create a rhythm by pounding the rice. It is the history of the art performance of Mappadendang in Bugis.

The traditional media such as Kecapi or Mappadendang are not monotonous although it has been listened for times. It caused by the Kecapi or Mappadendang players are really creative in creating a fresh humor and movement so those performances are relly entertaining, even there are some interactions between the players and the audiences. Therefore, the people feels that they are owning them. It means that as long as the society is exist, the cultural art of Kecapi and Mappadendang will be always exist even if not every individu is able to be the leader. Therefore, in order to keep their existance, there should be a serious effort of the Cultural Department to register them as a traditional media. Actually, the department has prepared the facilities which are needed in order to preserve all kinds of cultural art including Kecapi and Mappadendang. However Mr. Abduh explains that in order to get the facilities they have to be registered.

Especially, there should be an Indonesian Kecapi Community for preserving the art performance of Kecapi, that community will handle about how to empower the players which are mostly have low education. Therefore, it needs a professional organization in order to empower them. This kind of organization is expected to be able to decrease any kind of exploitation or deception toward the Kecapi players. That organization will give a protection and careness toward their right. Moreover, that organization is also able to pay attention toward the cadre aspect, so it can be handled well, thus the society are not worry about the future of that traditional media.

\section{The Existance of the Art Performance of Kecapi Based on the Face to Face Point of View}

The explanation that has been stated by Daeng Tutu, Mr. Rozak, Mr. Hafid, Mr. Haji Ma'ruf Saleh, Mr. Sabri, Mr. 
Haji Yunus, Mr. Salim, and Mr. Abduh are their way of thinking and understanding about the existance of the traditional media of the art performance of Kecapi which has been existed in the Buginese society, it also shows the fact about their existence. The form, playing process even the history are absolutely known and understood. It expresses their admires and appresiation toward the traditional media especially the art performance of Kecapi. As an individual who adores the art performance of Kecapi, they have an awareness to always preserve and make the traditional media of Kecapi to be popular. Moreover, they expect that there will be many sides who pay their attention in order to preserve the tradional media of the art performance of Kecapi, even other traditional medias, so the young generations who have a low attention about Kecapi can begin to like it. Therefore, it can be said that in truth they are really open-minded to accept new elements as long as do not decrease the existence and function of the art performance of Kecapi as the Buginese traditional media.

There is a high effectiveness of the messages which are delivered in the traditional media of the art performance because they are delivered by face to face communication directly, so it is enable of occuring a personal contact where the Sinrilik and Kecapi players may make a contact with the audiences. When the Pasinrilik and the Pakkacapi are delivering the messages, the audiences may give an immediate feedback at that moment. The players of the traditional media of art performance are able to know the audiences' response toward their messages, expressions, and stage movements directly. According to those conditions, the traditional media players as communicators are able to evaluate their performance, whether get a positive response from the audiences or in contrary they get a negative response because the audiences assume that the performance is not entertaining.

Therefore, Effendy (1993:62) states that a face to face communication is more effective in changing other's behavior. Because that kind of communication is using a persuasive communication technique, it means that a kind of communication technique is psichologically sensitive and contains of an atrratctive persuasion. However, he also explains that a communication technique of personally persuasion is only may performed in front of the potential audiences. It means that it should be performed by the player or elder who has a high influence in the society, so the performance is able to change the audiences' behavior or ideology, they will follow the messages which is delivered in that performance.

Retaled to the face to face communication as explained above, Devito (1997:259) remembering five important aspects which have to be considered in making a closer personally communication; Firstly, the openness of the communicator. The player who delivers the messages should be opened toward the audiences who will receive the messages, in this case it means that the player should be opened toward certain elements properly. Thus, the communicators may act honestly when they get a feedback or stimulous from the audiences. The communicators are also expected can admit that the feeling and thought which are delivered are from themselves and can be guaranteed. The best way to express the responsibility is by using the personal pronoun of "I".

Secondly, the feeling of empathy which means as an ability that have to be owned by the communicators in order to comprehend the audiences' feeling, comprehend the audiences' point of view by using their point of view. In order to be empathy, it can be practiced by control the desire of evaluating, commenting, and criticizing the audiences (it does not mean that those reactions are "wrong", but rather those are able to obstruct the audiences' comprehending). Meanwhile, more people that are the players known based on the desire, experience, ability even strength, they will have more ability in understanding the audiences' feeling. The empathy can be communicated verbally even nonverbally, for example is an active interaction between the players and the audiences through their expression and appropriate movements, doing a centrally consentration through the attentive eye contact, and other properly contact.

Thirdly, supportive action. It is related to the concept of openness and empathy, because both of them cannot be done in the unsupportive situation. The indication of a supportive action is when the players are explaining not evaluating, spontanious not strategic, act tentatively, open minded, want to listen an antipodes point of view, want to change the position if it is propered, and do not defensively over confidence so they are able to accept others' thought even idea.

Fourthly, positive action. It is important because the communication will be work well when the people inside have a positive behavior toward themselves or others, so they can support themselves in order to respect the importance and existance of other people. Fifthly, an equality, which is a main determining aspect in creating an impressing face to face communication. In this case, there must be an expressively or silently confession that every person who is involved in a communication has value, valuable and an important side. Thus, it can be explained that an equality means that every individual is able to accept the other, or giving a positive appresiasion toward the others without any requisite (see Goldberg, 1985: 71) 
The society and cultural condition of South Sulawesi in the form of custom, tradition also the alteration, including the the alteration of Kecapi performance, in the social aspect or the cultural changing, as the result is the comprehending in this review, that the alteration will always become their identity. Identity is an important aspect in the cultural perspective of media, because the identity is figuring the society and culture which is in the future it is able to help in comprehending the function and meaning of the activities which are done by the society itself.

\section{Closing}

Art performance of Kecapi is a kind of traditional media which is performed by Buginese people in order to deliver and accept variety of messages, it becomes the part of communication system of the Buginese society, where the communication system itself is involved in the part of social system of the Buginese people culture itself. Therefore, it can be concluded that the existance of the art performance of Kecapi as the kind of traditional media has a certain corelation with the communication system and socio culture system from the Buginese society as the owner and main supporter.

The art performance of Kecapi which is owned by the Buginese people has a characteristic, nature, position, and function even it can give a certain result and has a potency or strength which are able to influence the mindset and behavior of the Buginese people. Therefore, in packaging the messages which are going to be delivered by the Kecapi players as the communicator must consider about the audiences' demand and necessity as the messages receiver. Because, by that way the players as the communicators have understood the development demand of the era that tend to performing an art performance which is appropriate with the character and desire of the audiences.

The traditional media in the South Sulawesi is reputed as a "cultural commodity". It means that the program substance is a kind of commodity which is produced then may be sold (in the form of CD, DVD, Video tape, or the payment from the performances). Therefore, professionally it can be concluded that the traditional media is a valuable profession which should be appretiated, because in the production process it involves and exploits the people skill (collaboration process). The traditional media communities in the examination place express their ability by being the producer and cultural establisher. Their rule also as a social institution such as school and family which beside giving an entertainment, also doing other functions such as production, socialization, value teaching, education, giving information, even social control toward the children, youngsters, workers, ethnical groups, or other groups in the society. Based on that meaning, it can be concluded that culture is an exist activity in the society which is containing of a traditional media.

\section{References}

Abdullah, H. (1985). Manusia Bugis Makassar. Jakarta: Inti Idayu Press.

Abidin, A. Z. (1999). Capita Selekta Kebudayaan Sulawesi Selatan. Ujung Pandang: Hasanuddin U. Press.

Adhikarya, R., \& Crawford, R. (1979). The Use of Tradisional Media in Family Planning in Rural Java. Ithaca.

Afrisal et al. (2007). Media Rakyat; Mengorganisasi Diri Melalui Informasi. Jogjakarta: Combine Resource Institution Bekerja sama dengan The Ford Foundation.

Akib, Y. (2003). Potret Manusia Kajang. Makassar: Pustaka Refleksi.

Alfian. (1977). Sistem-Sistem Komunikasi dalam Masyarakat Indonesia. Jakarta: Lekna - Deppen.

Anoymous. (1994). Syekh Yusuf Makassar; Seorang Ulama, Sufi dan Pejuang. Jakarta: Yayasan Obor Indonesia.

Anoymous. (1995). Living Tradisions. Manila: Asean Committee on Culture and Information.

Anoymous. (2000). La galigo Jilid II. Diterjemahkan oleh H. Muh. Salim dan Fachruddin Ambo Enre. Makassar: Lembaga penerbitan Universitas Hasanuddin.

Anoymous. (2003). Permaianan Rakyat Sulawesi Selatan. Makassar: Lamacca Press.

Anoymous. (2005). Komunikasi \& Modernisasi. Bandung: CV. Mandar Maju.

Arief, A., \& Hakim, Z. (1993). Sinrilikna Kappalak Tallumbatua. Jakarta: Yayasan Obor Indonesia.

Bachtiar, A. (1984). Geschichte Und Gegenwart der Kommunikations Sistem in Indonesia. Frankfurt.

Barnard, M. (1996). Fashion Sebagai Komunikasi; Cara Mengkomunikasikan Identitas Sosial, Seksual, Kelas, Dan Gender. Diterjemahkan Oleh Idi Subandy Ibrahim. Jogjakarta: Jalasutra.

Burton, G. (2008). Pengantar untuk Memahami Media Dan Budaya Populer. Jogjakarta: Jalasutra. 
Cangara, H. (2000). Pengantar Ilmu Komunikasi. Jakarta: PT. Raja Grafindo Persada.

Dahlan, A. (1983). Tantangan Komunikasi Bagi Pembangunan, Tantangan Pembangunan Bagi Komunikasi. Makalah Seminar. Ujung Pandang: Universitas Hasanuddin.

Dananjaya, J. (1972). Bagaimana Memanfaatkan Media Tradisional Bagi Pembangunan Desa. Jakrta: Grafiti.

Dananjaya, J. (1994). Folklor Indonesia: Ilmu Gosip, Dongeng dan Lain-lain. Jakarta: Grafiti.

Dasen, P. R., \& Mishra, dan R. C. (2000). Cross-Cultural Views on Human Development in the Third Millennium. Internasional Journal of Behavioral Development. 24(4) 428-434.

Dashefsky, A. (Ed.) (1976). Ethnic identity in Society. Chicago: Rand Memelly College.

Departemen Komunikasi dan Informatika Republik Indonesia. (2007). Kerangka Acuan Arah Pengembangan dan Pemberdayaan Lembaga Media tradisional. Jakarta. Direktorat Kelembagaan Komunikasi Sosial Ditjen. Sarana Komunikasi dan Diseminasi Informasi.

Fisher, B. A. (1986). Teori-Teori Komunikasi. Penerjemah. Soejono Trimo. Bandung: Remadja Rosdakarya.

Foley, J. M. (1981). Oral Traditional Literature. Colombus Ohio: Slavica Publishers Inc.

Guerrero, L. K., \& Floyd, K. (2006). Nonverbal Communication In Close Relationships. New Jersey: Lawrence Erlbaum Associates, Publishers Mahwah.

Hamid, A. (2007). Pesan-Pesan Moral Pelaut Bugis. Makassar: Pustaka Refleksi.

Hamidy. (1975). Randai Sebagai Saluran Media Komunikasi Tradisional. Makalah Seminar.

Hamzuri, \& Siregar, T. R. (1998). Permainan Tradisional Indonesia. Proyek Jakarta: Pembinaan Permeseuman Direktorarat Jenderal Kebudayaan Departemen Pendidikan Dan Kebudayaan.

Hardwick, C. (1973). Traditions, Superstitions, and Folk-lore. England: The Scolar Press Limited Menston.

Hidayah, Z. (1997). Ensiklopedi Suku Bangsa di Indonesia. Jakarta: LP3ES.

Jahi, A. (1988). Komunikasi Massa dan Pembangunan Pedesaan di Negara-Negara Dunia Ketiga. Jakarta.

Joko. (1975). Pemimpin Agama dan Media Komunikasi Tradisional di Pedesaan. Jogjakarta: Makalah Seminar.

Kumaria, A. (1980). Communication and Tradisional Media. Proceedings of a seminar hald at Prune. Dalam Communicator 15 (1980)3, pp 12-17.

Leckenby, J. D., \& Collier, E. D. Centennial. (2003). The Interaction of Traditional and New Media. Texas: Departement of Advertising College of Communication, The University of Texas at Austin.

Littlejohn, S. W. (2002). Theories of Human Communication. New Mexico: Wadsworth Publishing Company.

MacDonal, M. R. (1993). The Oryx Multicultural Folktale Series; Tom Thumb. Canada: Oryx Press.

Mahmud et al. (2000). Struktur Cerita "Budi Istiharah" Sastera Bugis. Jakarta: Pusat Bahasa Departemen Pendidikan Nasional.

Majalah Masyarakat Indonesia Tahun ke IX No 1, 1982.

Majalah Sureq Edisi II/V/2008

Majalah Sureq Edisi III/VII/2008

Majalah Sureq Edisi IV/1/2008

Mame, A. R. et al. (1978). Adat dan Perkawinan Daerah Sulawesi Selatan. Ujung Pandang: Pusat Penelitian Sejarah dan Budaya.

Mattulada et al. (1977). Geografi Budaya Daerah Sulawesi Selatan. Jakarta: Proyek Penelitian dan Pencatatan Kebudayaan Daerah Departemen Pendidikan Dan Kebudayaan.

Mieder, W. (1987). Tradition And Innovation In Folk Literature. Honover: University Press of New England.

Monoharto, G., \& Kawan-kawan. (2003). Seni Tradisional Sulawesi Selatan. Makassar: Lamacca Press.

Muhtamar, S. (2007). Masa Depan Warisan Luhur Kebudayaan Sulsel. Makassar: Pustaka Refleksi.

Nurudin. (2004). Sistem Komunikasi Indonesia. Jakarta: PT Raja Grafindo Persada.

Oepen, M. (1988). Media Rakyat: Komunikasi Pengembangan masyarakat. Jakarta: P3M.

Onong Uchjana Effendy. (1993). Ilmu, Teori \& Filsafat Komunikasi. Bandung: PT. Citra Aditya Bakti. 
Orewere, B. (1991). Posible Implications of Modern Mass Media for Tradisional Communication in a Nigerian Rural Setting. Africa Media Review Vol. 5 No. 3. Nigeria: African Council for Communication Education.

Paeni, M., \& Pudentia. (2005). Bunga Rampai Budaya Berpikir Positif Suku-Suku Bangsa. Jakarta: Departemen Kebudayaan dan Pariwisata bekerjasama Dengan Asosiasi Tradisi Lisan (ATL).

Panuju, R. (1996). Sistem Komunikasi Indonesia. Jogjakarta: Pustaka Pelajar.

Putra, H. S. A. (2007). Patron \& Klien di Sulawesi Selatan Sebuah Kajian Fungsional Struktural. Jogjakarta: Kepel Press.

Rahman, N. (2005). Katalog Tradisi Lisan Komunitas Adat Terpencil Sulawesi Selatan. Makassar: Lagaligo P.

Razak, A. (2008). Eksistensi Pakacaping: Budaya Ekspresi Masyarakat Gowa Sulawesi Selatan. Jogjakarta: Lanarka Publisher.

Sikki, M. et al. (1998). Nilai dan Manfaat Pappaseng dalam Sastera Bugis. Jakrta: Pusat Bahasa Departemen Pendidikan Nasional.

Stokes, J. (2007). How To Do Media and Cultural Studies Panduan Untuk Melaksanakan Kajian dalam Kajian Media dan Budaya. Penterjemah Santi Indra Astuti. Jogjakarta: Bentang Pustaka.

Sukatanya, Y., \& Monoharto, G. (2000). Makassar Doeloe Makassar Kini Makassar Nanti. Makassar: Yayasan Losari Makassar.

Susanto, A. S. (1977). Komunikasi dalam Teori dan Praktek 1. Bandung: Binacipta.

Sutherland, H. et al. (2004). Kontinuitas \& Perubahan Dalam Sejarah Sulawesi Selatan. Disunting Oleh Dias Pradadimara \& Muslimin A.R. Effendy. Jogjakarta: Ombak.

Syahril, N. A. (1999). Sastera Bugis Klasik. Jakarta: Pusat Bahasa Departemen Pendidikan Nasional.

Tang, M. R. (2002). La Dadok Lele Angkurue; Sebuah Legenda Dalam Sastera Bugis Kuno Pra-Islam. Jakarta: Pusat Bahasa Departemen Pendidikan Nasional.

Tiongsong, N. G. (1986). The Cultural Traditional Media of Asean. Manila: Asean committee on Culture and Information.

Toa, A. P. (1995). I La Galigo Jilid I .Diterjemahkan oleh H. Muh. Salim dan Fachruddin Ambo Enre. Jakarta: Djambatan.

Vansina, J. (1972). Oral Tradition; A Study in Historical Methodology. London: Routledge \& Kegan Paul.

Wahid, S. (2007). Manusia Makassar. Makassar: Pustaka Refleksi.

\section{Notes}

Note 1. Buginese is one of four biggest ethnic in the South Sulawesi-Indonesia. The other ethnics are Makassar, Mandar and Toraja.

Note 2. The performance is occasionally begin since after praying Isya until befor praying Subuh.

Note 3. Kecapi is a traditional music which is made from wood, it is played by picking, while pakkacapi is a person who plays it. The picture of Kecapi can be seen on the appendix 3.

Note 4. Songkok to Bone is a unique head cover from South Sulawesi which is wore by the former noble, but nowadays it is wore by social people. This head cover or hat is made from the plaited rattan which is layered by gold thread. (See picture in the appendix 4).

Note 5. The case that is faced by Mr. Sabri is also faced by other heritage media players. It happens because of the less understanding of the heritage media player about contract, control, license, royalty, and so on. It is also caused by the less of advocacy from a certain sides in order to preserving the heritage media collection and the players.

Note 6. Alu is a utility to pound rice which is made from a round wood within the size is between 150 to $200 \mathrm{~cm}$, while palungeng is a place to put the rice that going to be pounded which is like a boat and is also made from wood. In the villages, this tool is used for pounding rice so it can be eaten. (See picture in the appendix 6).

\section{Copyrights}

Copyright for this article is retained by the author(s), with first publication rights granted to the journal.

This is an open-access article distributed under the terms and conditions of the Creative Commons Attribution license (http://creativecommons.org/licenses/by/4.0/). 